\title{
MEMBANGUN TUNAS INTEGRITAS SEBAGAI CIKAL GENERASI ANTIKORUPSI DI TINGKAT PENDIDIKAN DASAR
}

\author{
I PUTU ANDRE SUHARDIANA \\ Institut Hindu Dharma Negeri Denpasar \\ putuandresuhardiana@gmail.com
}

\begin{abstract}
A series of efforts in order to minimize corruption in Indonesia has been conducted on an ongoing basis. The formation of Indonesia's Corruption Eradication Commission (KPK) is one of the real actions of preventing corruption in a holistic manner, both preventively and curatively. Considering the vast territory of Indonesia and the large population, the emergence consistency of corruption cases is an indicator of the powerless of Indonesia's Corruption Eradication Commission $(K P K)$ to stem this problem independently. This Commission needs support. Families, schools, and societies as frontlines in forming high quality individuals who are not having legal defect in the acts of corruption, are tremendous assets and weapon whose role needs to be maximized in various lines of combating corruption. Schools, for example, this place is the first capital in forming anticorruption generation through the implementation of flagship programs related to the outage of corruption guerrilla which increasingly rampant recently. Specifically, the primary school is the most important force, because in this place, the children transitional period between the early age to teenager are getting the forging of character formation that covers all aspects, not only the improvement of cognitive side. Planting positive personality through a series of anti-corruption activities should be integrated in various subjects that are packaged in such a way that is interesting to be accepted by students. This is an activity that can no longer be delayed for its implementation. Moreover, the students are given the opportunity to develop their knowledge and logical reasoning on the various dimensions of anti-corruption, because the essential characteristics of anti-corruption education are the synergy between the use of information and knowledge with the ability to make moral judgments. If all parties are actively involved in its application, then it will be an investment program of long-term corruption prevention actions. Surely this is the dream of all citizens in order to create good governance which would impact on the welfare of the people as much as possible.
\end{abstract}

Keywords: Integrity Shoots, Anti-Corruption Generation, Primary Education

\section{Pendahuluan}

Kasus korupsi merupakan permasalahan serius di negara Indonesia. Korupsi telah menjadi kejahatan yang luar biasa (extra ordinary crime), disebabkan karena jenis kejahatan ini terjadi secara sistemik, terorganisasi di semua sektor kehidupan. Pada tahun 2007, pemerintah melalui Komisi Pemberantasan Korupsi (KPK) telah mencanangkan program kerja yaitu melakukan upaya kuratif yang diharapkan mampu memberikan hasil seketika. Walaupun upaya kuratif memberikan efek secara langsung, namun jangkauan tindak pidana korupsi telah terjadi secara luas sehingga upaya preventif dipandang perlu untuk dilakukan. Upaya preventif ini haruslah melibatkan semua unsur mulai dari lingkungan keluarga, sekolah, hingga pendidikan tinggi.

Upaya preventif yang bertujuan menumbuhkan generasi bersih dan antikorupsi ini telah dilakukan melalui kerjasama KPK, Kementerian Pendidikan Nasional, dan sekolah. Seperti yang tercantum dalam pasal 13 UU. No. 30 Tahun 2002 tentang Pemberantasan Tindak Pidana Korupsi, bahwa KPK berhak menyelenggarakan program pendidikan antikorupsi bekerja sama dengan Depdiknas pada seluruh tahapan pendidikan lewat komunikasi, sosialisasi, dan pendidikan. Dengan demikian generasi penerus bangsa dituntut dapat tumbuh menjadi generasi antikorupsi, dan sehubungan dengan hal inilah pendidikan antikorupsi terus digalakkan pada seluruh 
instansi pendidikan (Suciptaningsih, 2014).

Namun, harapan pemerintah ini cenderung tidak sesuai dengan kenyataan yang ada. Di tengah gencarnya kampanye pendidikan antikorupsi, justru korupsi yang mengarah pada tindak pidana dilakukan oleh kaum intelektual. Sebagai contoh, kasus korupsi pengadaan lahan Dermaga Gunaksa oleh mantan Bupati Klungkung, Dr. I Wayan Candra, S.H., M.H. Padahal, beliau adalah kaum intelektual yang menyandang gelar pendidikan tertinggi (beritadewata.com, 2014). Kemudian, yang lebih mencengangkan adalah terlibatnya Dr. $\mathrm{H}$. M. Akil Mochtar, S.H., M.H. selaku Ketua Mahkamah Konstitusi dalam kasus suap pemenangan salah satu kandidat dalam Pemilihan Kepala Daerah (Pilkada) di beberapa kabupaten/kota di Indonesia. Mereka adalah sebagian kecil dari pelaku tindak pidana korupsi. Dengan adanya keterlibatan tokoh intelektual, pejabat publik, Bupati, dan penyelenggara pemerintah dalam kasus korupsi di Indonesia, maka tidaklah mengherankan jika Indeks Persepsi Korupsi Indonesia berada pada ranking 107 dari 175 negara dalam survei yang dilakukan oleh Transparency International tahun 2014. Indonesia tentu masih sangat kalah dari Singapura yang menjadi satu-satunya negara di kawasan Asia Tenggara yang menduduki peringkat ke-7 sebagai negara paling bersih dari korupsi (liputan6.com, 2014). Sungguh prestasi yang memprihatinkan bagi negara kita.

Memasuki tahun 2045 Indonesia akan mendapatkan bonus demografi yaitu menempatkan kelompok usia produktif dalam skala besar. Sudah sepatutnya kondisi ini menjadi hal yang menguntungkan dalam rangka pencapaian kesejahteraan dan kestabilan ekonomi seluruh rakyat Indonesia. Akankah hal itu dapat terwujud? Sumber daya manusia yang berkualitas dan karakter antikorupsi adalah hal mutlak yang harus disiapkan.
Mengingat saat ini spektrum perilaku korupsi sangat luas dan tidak bisa dihentikan secara instan, maka diperlukan upaya menciptakan tunas-tunas integritas yang dilakukan melalui penerapan pendidikan antikorupsi. Pendidikan antikorupsi adalah upaya preventif untuk tidak melakukan tindak pidana korupsi yang bertujuan untuk mencegah terbentuknya koruptor. Dalam dunia pendidikan, pendidikan antikorupsi bukanlah menjadi sebuah pelajaran tersendiri, melainkan terintegrasi melalui beberapa mata pelajaran dalam tujuannya untuk menanamkan nilai-nilai antikorupsi.

Pelaksanaan

pendidikan antikorupsi oleh KPK telah dilakukan melalui pembuatan komik dan modul bagi siswa maupun guru dari tingkat sekolah dasar hingga perguruan tinggi. Efektifkah pendidikan antikorupsi terbatas pada penggunaan komik dan modul? Suciptaningsih (2014) menyatakan bahwa komik dan modul tersebut belum digunakan secara maksimal untuk menyebarluaskan nilai-nilai antikorupsi karena hal tersebut hanya mengarah pada aspek kognitif saja. Pada hakikatnya, pendidikan antikorupsi ini harus diaktualisasikan secara nyata dalam kehidupan sekolah. Karena pada dasarnya siswa tidak hanya belajar secara kognitif dan mengetahui nilai-nilai antikorupsi, melainkan secara afektif mampu bersikap serta psikomotornya mampu mengaktualisasikan perbuatan-perbuatan yang mencerminkan perilaku antikorupsi. Didukung pula oleh Subagia, dkk. (2006), bahwa proses belajar adalah aktifitas menyeluruh (fisik dan mental) yang dilakukan dengan cara perlahan serta berkelanjutan dalam rangka menambah pengetahuan dan keterampilan. Ini berarti bahwa belajar adalah sebuah proses yang menggunakan kemampuan dasar manusia, diantaranya kemampuan untuk bergerak, berbicara, serta kemampuan berpikir.

Jenjang pendidikan dasar, khususnya sekolah dasar merupakan 
tempat pembentukan moral siswa karena tempat ini secara sengaja dikondisikan untuk kegiatan belajar. Pendidikan antikorupsi dimaknai sebagai pendidikan nilai, budi pekerti, moral, serta watak yang tujuannya adalah untuk mengembangkan kemampuan siswa untuk dapat memberikan keputusan baik ataupun buruk, membedakan perilaku jujur maupun curang, dan mewujudkannya dalam kehidupan sehari-hari. Guru selaku ujung tombak pendidikan di sekolah memiliki peranan sangat penting untuk memberikan secara langsung sebuah pengalaman dan pembiasaan suatu kegiatan kepada siswa berkaitan dengan aktivitas yang memiliki nilai antikorupsi. Beberapa nilai yang terkandung pada pendidikan antikorupsi (Lembaga Administrasi Negara, 2014), yaitu: 1) jujur, 2) peduli, 3) mandiri, 4) disiplin, 5) tanggungjawab, 6) kerjakeras, 7) sederhana, 8) berani, dan 9) adil. Jika guru memahami dengan baik nilai-nilai dalam pendidikan antikorupsi, maka penanaman nilai dapat dilakukan dengan membiasakan siswa untuk: 1) bertindak jujur dengan tidak menyontek, 2) jujur untuk mengakui kesalahan, 3) mengembalikan barang yang bukan menjadi hak miliknya, dan berbagai kegiatan positif lainnya.

Jika dibandingkan dengan strategi pemberantasan korupsi yang lain, penerapan pendidikan antikorupsi di sekolah dasar secara formal akan memberikan beberapa keuntungan kepada negara baik secara pragmatis ataupun secara teoritis dan filosofis. Yang pertama, lembaga pendidikan formal merupakan lembaga yang tingkat kestabilannya sudah baik. Kedua, hal ini tidak menambah anggaran belanja pemerintah secara besarbesaran. Ketiga, kegiatan ini dapat diterapkan melalui jalan yang sistematis dan berkelanjutan, dan terakhir merupakan investasi jangka panjang bangsa Indonesia. Perlunya pendidikan antikorupsi sebenarnya telah menjadi unsur dari pendidikan nasional seperti yang tertuang dalam Peraturan Menteri Pendidikan Nasional (Permendiknas) No. 22 dan No. 23 Th. 2006 tentang Standar Isi dan Standar Kompetensi Lulusan bagi satuan pendidikan dasar dan menengah. Pada Permendiknas tersebut disebutkan bahwa pengembangan sikap dan perilaku antikorupsi adalah bagian dari kurikulum bidang studi Pendidikan Kewarganegaraan (PKn). Tugas utama dari pendidikan antikorupsi di sekolah adalah untuk memberikan pemahaman kepada siswa bagaimana mereka dapat membedakan antara kejahatan korupsi dengan bentuk kejahatan yang lain, selain itu siswa juga diharapkan mampu memberikan opini yang logis dan rasional tentang kegiatan korupsi yang dianggap sebagai sebuah kejahatan, serta memberikan metodemetode yang dapat diambil dalam rangka mengurangi terjadinya kejahatan korupsi (Modern Didactic Center, 2006).

Hal yang sama dinyatakan oleh Dharma (2003). Secara umum tujuan pendidikan antikorupsi adalah: (1) membentuk pengetahuan dan pemahaman tentang jenis tindakan korupsi dan bagianbagiannya; (2) perubahan pandangan dan sikap terhadap korupsi; dan (3) pembentukan keterampilan serta kecakapan baru yang memiliki tujuan untuk melawan tindak pidana korupsi. Dengan ketiga tujuan itu dapat dilihat bahwa pendidikan antikorupsi walaupun memiliki tujuan utama sebagai pendidikan nilai, akan tetapi tetap meliputi ketiga ranah pendidikan seperti yang disampaikan oleh Bloom yaitu pengembangan ranah kognitif, afektif dan psikomotor siswa. Berdasarkan rumusan yang dikemukakan oleh Komisi Pemberantasan Korupsi (KPK), terdapat sembilan nilai dasar yang perlu ditanamkan dan diperkuat dengan terlaksananya pendidikan antikorupsi di sekolah, nilai tersebut antara lain adalah kejujuran, adil, berani, hidup sederhana, tanggungjawab, disiplin, kerja keras, hemat dan mandiri. Kesemua nilai di atas 
sebenarnya sudah ada di masyarakat sejak zaman dahulu, dan secara jelas terdapat dalam dasar negara Pancasila, namun mulai tergerus oleh budaya konsumerisme yang dibawa oleh arus globalisasi dan modernisasi.

Sejalan dengan maksud yang hendak dicapai, implementasi pendidikan antikorupsi di sekolah harusnya memperhatikan beberapa hal (Modern Didactic Center, 2006) diantaranya adalah pengetahuan tentang korupsi. Agar dapat memiliki pengetahuan yang jelas tentang korupsi, siswa perlu mendapatkan berbagai informasi yang memungkinkan mereka mampu mengenali tindakan korupsi dan juga dapat membedakan antara kejahatan korupsi dengan kejahatan-kejahatan yang lain. Untuk itu pembahasan tentang kriteria, penyebab, dan akibat tindakan korupsi adalah bagian utama yang harus disampaikan kepada siswa. Selain itu siswa juga diharapkan mempunyai argumen yang tepat terhadap tindakan korupsi yang disebut sebagai tindakan yang tidak baik serta harus dijauhi. Dengan adanya perhitungan tentang sebab dan akibat dari tindakan korupsi pada berbagai aspek kehidupan manusia, termasuk aspek moralitas akan membuka wawasan siswa tentang korupsi secara luas. Tujuan dari hal ini tidak lain adalah dengan adanya bermacam-macam alternatif yang bisa digunakan untuk menghindari tindak pidana korupsi, maka diharapkan dapat menjadi inspirasi bagi siswa tentang banyaknya variasi metode yang dapat dilakukan dalam proses pemberantasan korupsi. Semua hal ini merupakan modal dasar menanamkan dan membentuk perilaku serta karakter antikorupsi. Atas dasar pengetahuan tersebut para siswa diharapkan dapat menilai adanya tindakan korupsi pada masyarakat atau institusi disekitarnya. Sehingga pemberian informasi mengenai korupsi tidak semata bertujuan untuk memberikan informasi sebanyakbanyaknya pada siswa, melainkan informasi tersebut diperlukan dalam hubungannya agar siswa memiliki beberapa pertimbangan yang benar dalam memberikan penilaian. Dengan kata lain berdasarkan informasi dan pengetahuannnya mengenai kejahatan korupsi, siswa pada akhirnya diharapkan mampu memberikan penilaian apakah suatu perbuatan itu termasuk korupsi atau tidak, dan apakah tindakan itu termasuk tindakan baik atau buruk. Melalui pertimbangan tersebut selanjutnya siswa dengan otomatis akan mampu menentukan perilaku yang akan diambilnya.

Hal selanjutnya adalah pengembangan sikap sebagai bagian dari pendidikan nilai serta sifat atau karakter, kaitannya dengan hal ini adalah pendidikan antikorupsi memberikan atensi besar pada pengembangan aspek sikap siswa. Sikap adalah serangkaian penilaian yang ditujukan pada suatu objek/tujuan yang dititikberatkan atas dasar pengetahuan, reaksi afektif, kemauan, dan perilaku sebelumnya terhadap objek tersebut (Fishbean, \& Ajzen 1973). Kesemua elemen di atas saling berhubungan serta saling mengisi, sebagai contoh reaksi afektif dapat diikuti oleh perilaku yang biasa dilakukan siswa. Karena itu sikap pro terhadap tindakan korupsi bukanlah semata sebuah kategori, melainkan juga mengandung hal lainnya. Perubahan pada satu bagian tentunya akan merubah bagian yang lain. Sebagai contoh penghilangan intensi dan perilaku kemungkinan akan merubah kognisi, sikap, dan reaksi secara afektif. Oleh sebab itu pada saat pemberian informasi mengenai tindakan korupsi, guru diharapkan dapat mencoba mengembangkan perilaku siswa didasarkan atas pengetahuan/kognisi yang mereka miliki. Dalam hal ini siswa harus memiliki pengetahuan/kognisi yang benar dan dipahami secara baik, sehingga pengetahuan tersebut dapat tersimpan lama dalam ingatannya serta dapat digunakan 
setiap kali mereka akan membuat pertimbangan-pertimbangan tertentu.

Disamping itu keterlibatan yang intens dalam aktivitas yang mengandung berbagai nilai antikorupsi tentunya akan meningkatkan perilaku yang sesuai dengan nilai tersebut. Perubahan sikap yang melekat sebelumnya adalah bentuk pekerjaan dan tanggungjawab yang tidak gampang dan terkadang menimbulkan rasa frustrasi. Apalagi ketika perilaku yang melekat tersebut bertentangan dengan sikap yang dikehendaki guru atau tenaga pendidik, misalnya sikap yang menganggap kecurangan dalam ujian adalah hal yang tidak aneh atau biasa dilakukan oleh siswa, atau menyontek pekerjaan rumah teman untuk diakui sebagai tugas sendiri merupakan hal yang lumrah. Perilaku seperti ini akan semakin berkembang dengan sikap buruk terhadap situasi di tengah-tengah masyarakat seperti memberi sogokan pada polisi dikarenakan adanya pelanggaran peraturan lalu lintas, dan lain sebagainya. Pendidikan antikorupsi menginginkan perilaku-perilaku seperti ini dihilangkan sehingga sinkron dengan berbagai nilai dasar antikorupsi. Maka, diperlukan pola dan strategi perubahan sikap yang bisa digunakan dari berbagai macam sumber, sebagai contoh untuk menciptakan pandangan tentang korupsi yang berlawanan dengan persepsi yang dimiliki siswa bisa dikerjakan dengan cara menyajikan informasi melalui metode yang tak terduga dengan permainan atau parodi. Strategi lain untuk perubahan perilaku adalah dengan mendasarkan semuanya pada bukti dan fakta bahwa pengetahuan dan sikap disimpan dalam tempat atau memori yang berlainan, sehingga hal ini tentunya memerlukan waktu untuk mencapai keduanya, artinya proses pengetahuan yang berubah menjadi sikap membutuhkan waktu yang lumayan lama. Sehingga kalau terdapat sikap yang pro pada korupsi sebaiknya tidak diserang secara langsung atau diminimalisir secara persuasif. Lama kelamaan sikap tersebut akan berubah dengan sendirinya apabila informasi yang melemahkan tindakan korupsi disampaikan dengan cara kreatif serta merangsang siswa untuk berpikir kritis mengenai realita tersebut. Karena disinilah terdapat sebuah reaksi yang disebut postponement effect (McInerney, 2006), dimana pada dasarnya informasi sulit untuk dipercayai akan tetapi kemudian pengetahuan yang benar akan mengatasi reaksi afektif.

\section{Pembahasan}

\subsection{Pengertian Antikorupsi}

Kata 'korup' menurut Kamus Besar Bahasa Indonesia berarti busuk, rusak, suka menerima sogokan, memakai kepentingan bersama untuk kepentingan pribadi. Sedangkan korupsi diartikan sebagai perbuatan yang buruk, seperti penggelapan uang, penerimaan uang sogokan dan sebagainya. Kata korupsi berasal dari bahasa latin yaitu corruptio yang artinya kerusakan, kebobrokan, dan kebusukan. Seirama dengan kata asalnya, korupsi sering dikatakan sebagai kejahatan luar biasa. Artinya, kejahatan ini menyebabkan dampak luas dalam ruang lingkup pribadi, keluarga, masyarakat, berbangsa dan bernegara (Lembaga Administrasi Negara, 2014).

Menurut Kamus Besar Bahasa Indonesia, kata 'anti' mengandung arti tidak setuju, tidak suka, dan tidak senang. Dalam hal ini, antikorupsi merupakan bentuk ketidaksukaan, penentangan dan perlawanan terhadap perilaku korup. Sikap antikorupsi adalah perilaku menentang korupsi untuk mencegah dan menghilangkan peluang berkembangnya korupsi.

\subsection{Identifikasi Nilai-Nilai Antikorupsi}

Termuat dalam Modul Pendidikan dan Pelatihan Prajabatan CPNS Golongan III tentang Antikorupsi oleh Lembaga Administrasi Negara Tahun 2014, dinyatakan bahwa KPK bersama pakar 
telah melakukan identifikasi nilai-nilai antikorupsi, dan dihasilkan sebanyak 9 (sembilan) nilai, yaitu: 1) jujur, 2) peduli, 3) mandiri, 4) disiplin, 5) tanggungjawab, 6) kerjakeras, 7) sederhana, 8) berani, dan 9) adil. Adapun makna nilai-nilai tersebut dapat dijabarkan sebagai berikut.

1. Jujur

Jujur dapat didefinisikan sebagai sebuah tindakan maupun ucapan yang lurus, tidak berbohong dan tidak curang. Jujur merupakan salah satu nilai yang paling utama dalam sikap antikorupsi. Dalam kehidupan seharihari, ketika orang berperilaku tidak jujur maka orang tersebut tidak akan mendapat kepercayaan dalam berbagai hal.

\section{Peduli}

Arti kata peduli adalah mengindahkan, memperhatikan, dan menghiraukan. Rasa kepedulian dapat dilakukan terhadap lingkungan sekitar dan berbagai hal yang berkembang di dalamnya. Bentuk nyata kepedulian terhadap sesama, yaitu: turut membantu jika terjadi bencana alam/musibah/kehilangan, serta turut membantu meningkatkan kebersihan lingkungan sekitar tempat tinggal maupun di lingkungan tempat bekerja baik dari sisi lingkungan alam maupun sosial terhadap individu dan kelompok lain.

3. Mandiri

Mandiri berarti dapat berdiri diatas kaki sendiri, artinya tidak banyak bergantung kepada orang lain dalam berbagai hal. Tanpa kemandirian, seseorang tidak akan mampu memimpin orang lain.

4. Disiplin

Disiplin memiliki makna ketaatan atau kepatuhan terhadap peraturan. Manfaat dari disiplin adalah tujuan dapat dicapai dengan waktu yang lebih efisien. Kedisiplinan dapat diwujudkan antara lain dalam bentuk kemampuan mengatur waktu dengan
http://ejournal.ihdn.ac.id/index.php/AW

baik, kepatuhan terhadap seluruh peraturan dan ketentuan yang berlaku, mengerjakan segala sesuatu dengan tepat waktu, serta fokus pada pekerjaan.

5. Tanggung jawab

Tanggungjawab adalah suatu keadaan di mana kita wajib menanggung segala sesuatunya. Seseorang yang memiliki rasa tanggung jawab akan memiliki kecenderungan menyelesaikan tugas dengan lebih baik. Seseorang yang dapat menunaikan tanggungjawabnya sekecil apapun dengan baik akan mendapatkan kepercayaan dari orang lain.

6. Kerja keras

Kerja keras harus berdasarkan niat dan kemauan. Bekerja keras merupakan hal yang penting guna mencapai hasil yang sesuai dengan tujuan yang ditetapkan.

7. Sederhana

Bentuk kesederhanaan diwujudkan dengan gaya hidup yang tidak hidup boros, dan sesuai dengan kemampuan. Dengan gaya hidup yang sederhana, seseorang juga dibina untuk memprioritaskan kebutuhan diatas keinginannya.

8. Berani

Wujud berani adalah mengatakan sesuatu yang benar dan membela kebenaran, berani mengakui kesalahan, serta berani bertanggungjawab. Untuk mencapai kesuksesan, keberanian sangat diperlukan. Keberanian harus dilandasi oleh kebenaran.

9. Adil

Adil artinya sama berat, tidak berat sebelah dan tidak memihak. Keadilan adalah penilaian dengan memberikan sesuatu kepada siapapun sesuai dengan apa yang menjadi haknya, yakni dengan bertindak proposional dan tidak melanggar hukum. Keadilan berkaitan erat dengan hak, dalam 
konsepsi bangsa Indonesia hak tidak dapat dipisahkan dari kewajiban.

\subsection{Pendidikan Antikorupsi}

Keterlibatan pendidikan formal dalam upaya pencegahan korupsi di Indonesia bukanlah hal yang baru. Ini terjadi mengingat sekolah adalah agen perubahan sosial yang berfungsi untuk memperkenalkan nilai-nilai baru kepada masyarakat (Hakim, 2012). Hal ini sejalan dengan hakekat pendidikan sebagai suatu usaha sadar dan bertujuan untuk mengembangkan kualitas manusia. Kualitas manusia yang dihasilkan berpedoman pada pengembangan pilar potensi kecerdasan manusia. Potensi kecerdasan tersebut yaitu: kecerdasan hati, kecerdasan rasa, kecerdasan otak, serta kecerdasan fisik (kinestetik) yang dikenal dengan istilah kecerdasan komprehensif. Kecerdasan komprehensif ini diteruskan pada setiap pribadi insan Indonesia, sehingga hal ini mampu menghasilkan insan yang beriman, bertakwa kepada Tuhan, cerdas, dan kompetitif terhadap perkembangan ilmu pengetahuan, teknologi dan seni (BSNP, 2007).

Sebagai agen perubahan, maka pendidikan antikorupsi di tingkat satuan pendidikan juga merupakan koreksi budaya yang bertujuan untuk memperkenalkan cara berfikir dan nilainilai baru kepada peserta didik. Pendidikan antikorupsi merupakan usaha sadar untuk memberikan pemahaman dan pencegahan terjadinya perbuatan korupsi yang dilakukan melalui pendidikan formal, pendidikan informal pada lingkungan keluarga, serta pendidikan nonformal di masyarakat. Pendidikan antikorupsi tidak berhenti pada pengenalan nilai-nilai antikorupsi saja, akan tetapi berlanjut pada pemahaman nilai, penghayatan nilai, dan pengamalan nilai antikorupsi yang tentunya harus menjadi kebiasaan hidup sehari-hari.

Tujuan pembelajaran pendidikan antikorupsi adalah: 1) pada saat terjun ke
http://ejournal.ihdn.ac.id/index.php/AW

masyarakat siswa telah mendapat bekal yang cukup untuk dapat memahami etika di setiap level 'social leaders' yang dijalaninya, 2) memahami secara komprehensif pentingnya etika baik di sektor publik maupun di sektor privat, 3) mengenali dan memahami dampak buruk korupsi terhadap kepercayaan masyarakat dan persaingan di dunia internasional, dan 4) memiliki keberanian dan kebijaksanaan untuk memberantas korupsi (Sjahrussin, 2006).

Dalam pendidikan antikorupsi tiga domain harus diintegrasikan, yakni domain pengetahuan (kognitif), sikap dan perilaku (afeksi), serta keterampilan (psikomotorik). Implementasi pendidikan antikorupsi di jenjang sekolah bisa menggunakan strategi eksklusif maupun studi kasus. Selanjutnya pendidikan antikorupsi adalah program pendidikan yang diselenggarakan di sekolah, dapat berbentuk penyisipan dalam materi mata pelajaran tertentu, ataupun diimplementasikan dalam bentuk materi kegiatan ekstra kurikuler siswa (Direktorat Madrasah, 2013).

\subsection{Bentuk Penerapan Nilai Antikorupsi}

Korupsi adalah salah satu bentuk pelanggaran moral. Luaran berupa moral yang baik adalah tujuan pendidikan, oleh karena itu suatu tantangan bagi dunia pendidikan untuk menanamkan, mengembangkan, dan melaksanakan nilai rasional, keberaturan, rajin dan sikap produktif. Tercapainya tujuan pendidikan ini akan mampu membawa manusia memiliki watak mulia, taqwa kepada Tuhan Yang Maha Esa, dan mempunyai nilai-nilai kemanusiaan terhadap sesama.

Penanaman nilai-nilai antikorupsi dapat dilakukan melalui pembudayaan dalam seluruh aktivitas dan suasana sekolah. Pembudayaan akan menimbulkan suatu pembiasaan. Untuk menumbuhkan budaya antikorupsi, sekolah perlu merencanakan suatu budaya dan kegiatan 
pembiasaan. Pembiasaan adalah alat pendidikan (Direktorat Madrasah, 2013). Pembiasan/aktualisasi tersebut adalah sebagai berikut.

\subsubsection{Penanaman Semangat dan Komitmen Antikorupsi yang Kuat}

Proses pembiasaan perilaku antikorupsi memerlukan adanya komitmen yang kuat dan tahan lama. Hal ini berarti komitmen secara terus menerus dengan berkelanjutan perlu dibangun. Pembiasaan perilaku antikorupsi harus disertai dengan penciptaan atmosfir yang mendukung melalui pembiasaan seperti "Salam" dan "Yel-yel" yang secara ekstrim dan eksplisit menolak perilaku korupsi. Salam antikorupsi bisa dikembangkan melalui pembiasaan pemberian salam seperti "Korupsi... No!", “Antikorupsi... Yes!" Setiap warga sekolah yang berjumpa di jalan atau tempat-tempat lain, atau dalam pertemuan-pertemuan warga sekolah, atau bahkan pada saat akan memulai dan mengakhiri pembelajaran di kelas, setelah pemberian salam. Pemberian salam dan jawabannya dilakukan dengan suara tegas penuh semangat. Hal lain yang dapat dilakukan adalah pemasangan poster atau karikatur yang mengandung nilai dan perilaku antikorupsi. Poster memuat slogan yang berupa kata-kata hikmat yang bermakna dan menimbulkan kesan mendalam. Poster hendaknya merupakan hasil karya siswa sehingga akan menumbuhkan rasa bangga pada diri siswa yang selanjutnya dapat memperkuat komitmen antikorupsi pada dirinya.

\subsubsection{Berprilaku Tanggungjawab \\ Terbuka, Menjunjung Tinggi Kepentingan Umum.}

Pembiasaan perilaku antikorupsi dapat dilakukan melalui kas kelas. Kebiasaan mengelola keuangan kas kelas secara jujur, transparan, dan penuh tanggung jawab akan dapat membentuk pembiasan terhadap perilaku tersebut. Kas kelas juga dapat membiasakan siswa untuk menjunjung tinggi serta lebih mengutamakan kepentingan umum daripada kepentingan pribadi.

\subsubsection{Berperilaku Jujur pada Diri Sendiri dan Orang Lain dalam Melakukan Transaksi}

Kejujuran adalah salah satu sikap utama yang mempunyai sumbangan besar terhadap perilaku antikorupsi. Pembiasaan perilaku antikorupsi berarti juga pembiasaan terhadap sikap kejujuran. Pembiasaan sikap kejujuran ini salah satunya dapat dilakukan melalui Kantin Kejujuran yang dikelola dengan semangat kejujuran yang tinggi. Rancangan model Kantin Kejujuran ini dapat didesain sesuai dengan kondisi sekolah masing-masing dengan tetap memperhatikan perlunya ada mekanisme kontrol atau pengawasan. Mekanisme kontrol atau pengawasan bisa dibuat, salah satunya dengan menyediakan buku 'transaksi mandiri' untuk mencatat segala jenis transaksi (barang yang dibeli, jumlahnya, harganya, uang pembayarannya, uang kembaliannya, dan sebagainya) secara mandiri oleh siswa yang membeli.

\subsubsection{Berperilaku Hanya Mau Menerima Sesuatu yang Memang Menjadi Hak atau Miliknya atau Tidak Mau Mengambil Sesuatu yang Bukan Miliknya \\ Salah satu perwujudan sikap jujur} adalah tidak mau memiliki sesuatu benda apa pun yang bukan miliknya, meskipun benda itu hasil temuan dan ternyata tidak ada yang memiliki. Pembiasaan sikap ini sangat efektif dan relevan untuk dapat menghindari perilaku korupsi. Salah satu upaya untuk membiasakan sikap tersebut adalah dengan mengadakan Pos Kehilangan dan Benda Tak Bertuan. Pos ini berfungsi sebagai tempat penampungan benda-benda yang ditemukan oleh setiap 
warga sekolah, baik yang ada pemiliknya maupun tidak ada pemiliknya. Warga sekolah yang merasa kehilangan sesuatu setiap saat bisa datang ke Pos tersebut untuk mencari apakah barang miliknya yang hilang ada ditemukan orang lain dan diserahkan ke Pos tersebut. Tata cara dan mekanisme kerja pada Pos Kehilangan dan Barang Tak Bertuan ini bisa dirancang dengan semangat prasangka baik, namun harus disertai dengan mekanisme klarifikasi dengan mencatat identitas diri dan barang miliknya yang diambil, bagi seseorang yang mengaku kehilangan barang harus menyebutkan ciri-ciri, warna, atau bentuk barang yang dimaksud. Bentuk kegiatan ini bertujuan menumbuhkan kebiasan antikorupsi di sekolah dasar sejak dini. Adanya kebiasaan yang baik tentu akan melahirkan bentuk prilaku yang baik pula dikemudian hari.

\section{Simpulan}

Pendidikan antikorupsi adalah sebuah kebijakan dalam bidang pendidikan yang tidak bisa lagi ditunda pelaksanaanya di sekolah secara formal. Apabila hal ini dikerjakan dengan baik dan maksimal maka dalam kurun waktu jangka panjang pendidikan antikorupsi akan mampu berkontribusi positif terhadap serangkaian usaha untuk mencegah munculnya kejahatan korupsi, seperti yang dialami oleh negara lain. Melalui pendidikan antikorupsi diharapkan para penerus bangsa mempunyai perilaku dan karakter antikorupsi serta dapat membebaskan negara Indonesia sebagai negara dengan angka korupsi yang tinggi. Karakteristik dari pendidikan antikorupsi salah satunya adalah adanya keseimbangan antara pemanfaatan informasi dan pengetahuan yang benar dengan kemampuan pembuatan pertimbangan-pertimbangan moral. Oleh karena itu pembelajaran antikorupsi tentunya tidak bisa dikerjakan melalui cara-cara konvensional, melainkan harus didesain sedemikian rupa sehingga aspek kognisi, afeksi, dan psikomotorik siswa mampu dikembangkan secara maksimal dan berkelanjutan.

Pengetahuan yang dalam serta memiliki makna baik mengenai antikorupsi akan memberikan pengaruh dalam pembentukan sikap antikorupsi pada siswa. Untuk itu proses pelaksanaan pendidikan harus dapat membuat siswa mengerti dan paham akan kriteria, sebab dan akibat dari korupsi. Seorang tenaga pendidik dapat menginformasikan ulang hal-hal terkait dengan berbagai cara yang berbeda agar siswa mengerti dengan jelas dan dapat menangkap maknanya. Bagian lain yang juga penting dari pendidikan antikorupsi adalah kemampuan siswa untuk membuat pertimbangan moral terkait tindakan korupsi, dan hal ini secara langsung melibatkan tingkat kognisi yang dimiliki.

Pendidikan antikorupsi tidak cukup melalui sosialisasi semata, melainkan harus diwujudkan melalui perilakuperilaku nyata. Kecenderungan yang terjadi adalah nilai-nilai antikorupsi akan tumbuh seiring dengan terjadinya pembiasaan-pembiasaan perilaku korupsi. Pemberantasan kasus korupsi dengan mewujudkan generasi antikorupsi melalui jalur pendidikan adalah upaya preventif pemerintah. Ketika antikorupsi masuk pada jalur pendidikan, maka pengembangan model kurikulum yang sesuai hendaknya menjadi perhatian stakeholder pendidikan. Selain itu, pembentukan karakter pendidik dan tenaga kependidikan dengan jiwa antikorupsi dapat dilakukan melalui penyelenggaraan pendidikan dan pelatihan di badan Diklat terkait. Pendidikan antikorupsi bukan merupakan serangkaian aturan mengenai perilaku yang dibuat oleh pihak-pihak terkait dan mesti diikuti oleh orang lain. Sama halnya dengan kejahatan lainnya, korupsi juga merupakan sebuah pilihan untuk dikerjakan atau dijauhi. Karena pendidikan pada dasarnya adalah 
mengkondisikan agar perilaku siswa sesuai dengan tuntutan masyarakat.

\section{DAFTAR PUSTAKA}

BSNP. 2007. Panduan Penilaian Kelompok Mata Pelajaran Ilmu Pengetahuan dan Teknologi. Jakarta: Departemen Pendidikan Nasional

Dharma, Budi. (2004). Korupsi dan Budaya. Tersedia dalam Kompas, 25/10/2003

Direktorat Madrasah. 2013. Panduan Penyelenggaraan Pendidikan Anti Korupsi di Madrasah. Direktorat Pendidikan Islam, Kementerian Agama RI

Elvandari, dkk. 2008. Menumbuhkan Nilai-Nilai Anti Korupsi Dalam Keluarga (Sosialisasi Program Anti Korupsi) Tersedia pada Warta Pengabdian Andalas Volume XIV, 21 Desember 2008

Fishbean, Martin \& Icek Ajzen. (1973). Belief, Attitude, Intention and Behavior: An Introduction to Theory and Research. Addison Wesley Publishing: USA

Hakim, Lukman. 2012. Model Integrasi Pendidikan Antikorupsi. Tersedia pada Jurnal Pendidikan Agama Islam-Ta'lim Vol. 10 N0. 2-2012

http://beritadewata.com/Hukum-dan-

Kriminal/Hukum/Mantan-Bupati-

Klungkung-\%E2\%80\%9CI-

Wayan-Candra\%E2\%80\%9D-

Ditahan.html diakses pada 2

Februari 2016

http://news.liputan6.com/read/2144872/ind eks-persepsi-korupsi-indonesia-

2014-naik-7-peringkat diakses pada 3 Februari 2016

Kamus Besar Bahasa Indonesia Versi Online

Laporan Aktualisasi Nilai Dasar Profesi Aparatur Sipil Negara Tahun 2015

Lembaga Administrasi Negara. 2014. Anti Korupsi (Modul Pendidikan dan
http://ejournal.ihdn.ac.id/index.php/AW

Pelatihan Prajabatan Calon

Pegawai Negeri Sipil Golongan III.

McInerney, Denis M. 2006.

Developmental Psychology for

Teacher. Allen \& Unwin: Australia

Modern Didactic Center. 2006. Anti

Corruption Education at School.

Garnelish Publishing: Vilnius.

Lithuania

Setiawan, A. 2012. Konseling tersedia pada

http://andiysetiawan.blogspot.com/

2012/11/ empati.html diakses pada 20 Juli 2015

Sjahrussin, R. 2006. Makalah KPK dalam

Seminar Nasional tanggal 13 September 2006.

Subagia, dkk.2006. Potensi-Potensi Kearifan Lokal Masyarakat Bali Dalam Bidang Pendidikan termuat pada Jurnal Pendidikan dan Pengajaran IKIP Negeri Singaraja, No. 3 TH. XXXIX Juli 2006

Suciptaningsih, O. A. 2014. Pendidikan Anti Korupsi Bagi Siswa Sekolah Dasar di Kecamatan Gunungpati. Universitas PGRI Semarang

UU No. 30 Tahun 2002 tentang

Pemberantasan Tindak Pidana Korupsi 